\title{
Hyperbaric oxygen therapy and mechanical resistence of the colonics anastomosis in rats with peritonitis ${ }^{1}$
}

\author{
Oxigenoterapia hiperbárica e resistência mecânica das anastomoses cólicas em ratos com \\ peritonite
}

\author{
Antonio Angelo Rocha', Raquel Franco Leal' ${ }^{\mathrm{II}}$, Maria de Lourdes Setsuko Ayrizono ${ }^{\mathrm{II}}$, Wu Feng Chung ${ }^{\mathrm{III}}$, Cláudio Saddy Rodrigues \\ Coy $^{\mathrm{IV}}$, Huei Diana Lee ${ }^{\mathrm{V}}$, João José Fagundes ${ }^{\mathrm{VI}}$ \\ ${ }^{I}$ Master, Post-graduate Program in Surgery, UNICAMP, Campinas-SP, Brazil. \\ ${ }^{\text {II }} \mathrm{PhD}$, Assistant Professor, Digestive Tract Diseases, Surgery Department, UNICAMP, Campinas-SP, Brazil. \\ III PhD, Researcher Professor, Surgery Department, UNICAMP, Campinas-SP. Bioinformatics Laboratory (LABI) Coordinator, UNIOESTE, Foz do \\ Iguaçu-PR, Brazil. \\ Iv PhD, Full Professor and Coloproctology Group Coordinator of Surgery Department, UNICAMP, Campinas-SP, Brazil. \\ ${ }^{v} \mathrm{PhD}$, Assistant Professor, Computer Science Course and Coordinator of the LABI, UNIOESTE, Foz do Iguaçu-PR, Brazil. \\ ${ }^{v i} \mathrm{PhD}$, Full Professor, Coloproctology Group of Surgery Department, UNICAMP, Campinas-SP, Brazil.
}

\begin{abstract}
Purpose: To analyze the effects of hyperbaric oxygen therapy (HBO) on the mechanical resistance of anastomosis performed in rats' distal colon presenting peritonitis induced by ligature and cecal punction using the Total Energy Rupture biomechanical test (ETR). Methods: It was used 45 rats divided into three groups of 15 animals each. In Control Group (CG), it was performed anastomosis in distal colon without peritonitis. In Peritonitis Group (PG), it was performed anastomosis six hours after the induction of peritonitis by ligature and cecal punction. In Hyperbaric Chamber Group (HCG), it was performed six hours after the induction of peritonitis by ligature and cecal punction. The animals on CG and PG were kept at place air while the animals on HCG were placed on an experimental hyperbaric chamber in order to inhale oxygen at 100\%, two absolute atmospheres, for 120 minutes, for four consecutive days. Euthanasia took place on the fifth day of the experiment. All the animals underwent to Total Energy Rupture Biomechanical Resistance test (ETR). Total Energy Rupture was defined as the necessary internal energy stored up to promote the colon rupture after an external traction force imposition. Results: The Peritonitis Group presents smaller average ETR than Control Group. There was no statistical difference between Peritonitis Group and Hyberbaric Chamber Group. Conclusion: Hyperbaric oxygen therapy did not alter the mechanical resistance of anastomosis performed in distal colon of rats under the presence of peritonitis induced by ligature and cecal puncture.
\end{abstract} Key words: Anastomosis, Surgical. Colon. Hyperbaric Oxygenation. Peritonitis. Rats.

\section{RESUMO}

Objetivo: Analisar o efeito da oxigenoterapia hiperbárica (HBO) sobre a resistência mecânica de anastomoses realizadas em cólon distal de ratos na presença de peritonite induzida por ligadura e punção cecal utilizando o teste biomecânico de Energia Total de Ruptura (ETR). Métodos: Foram utilizados 45 ratos distribuídos em três grupos de 15 animais. No Grupo Controle (GC), realizou-se anastomose no cólon distal sem peritonite. No Grupo Peritonite (GP), realizou-se anastomose seis horas após a indução da peritonite por ligadura e punção cecal. No Grupo Câmara Hiperbárica $(\mathrm{GCH})$, realizou-se anastomose seis horas após a indução da peritonite por ligadura e punção cecal. Os animais dos GC e GP foram mantidos em ar ambiente. Os animais do GCH foram colocados em uma câmara hiperbárica experimental para inalarem oxigênio a 100\%, a duas atmosferas absolutas, durante 120 minutos, por quatro dias consecutivos. A eutanásia ocorreu no quinto dia do experimento. Todos os animais foram submetidos ao Teste de Resistência Biomecânico Energia Total de Ruptura (ETR). A Energia Total de Ruptura foi definida como a energia interna acumulada necessária para promover o rompimento do cólon após a imposição de uma força externa de tração. Resultados: O Grupo Peritonite apresentou menor média de ETR que o Grupo Controle. Não houve diferença estatística entre o Grupo Peritonite e o Grupo Câmara Hiperbárica. Conclusão: A oxigenoterapia hiperbárica não alterou a resistência mecânica de anastomoses realizadas no cólon distal de ratos na presença de peritonite induzida por ligadura e punção cecal.

Descritores: Anastomose Cirúrgica. Cólon. Oxigenação Hiperbárica. Peritonite. Ratos.

${ }^{1}$ Research performed at the Division of Experimental Surgery, Department of Surgery, Campinas University (UNICAMP), São Paulo, Brazil. 


\section{Introduction}

The cicatrization of bowels anastomosis depends on local and systemic factors. Among the last ones, male sex, obesity, malnutrition, hipoalbuminemia, smoking habits, alcohol consumption, leukocytosis, intrasurgical blood transfusion, cardiovascular diseases, chronicle obstructive pulmonary diseases and emergency surgeries in patients presenting two or more of the previews diseases in association are remembered as contributing factors to the dehiscence risk increasing ${ }^{1,2}$.

Nowadays, the dehiscence index in colorectal surgery range from $1,8 \%{ }^{1}$ to $2,8 \%{ }^{3}$. reach $32 \%{ }^{1}$.

They represent its main cause of mortality ${ }^{3}$, which can

As the surgical techniques and the suture materials, other factors interfere in anastomosis quality, as antibiotics ${ }^{4,5}$, antioxidants $^{6,7}$, antineoplasics ${ }^{8}$, imunossupressors ${ }^{9}$, hormones $^{10}$, trauma $^{11}$, shock $^{12-14}$, adherences ${ }^{15,16}$ and ischemia ${ }^{17,18}$.

Besides the mentioned factors, peritonitis is an important factor that can alter the cicatrization of anastomosis in bowels ${ }^{19-29}$.

The HBO consists on inhaling oxygen at $100 \%$ in a pression superior to the atmospheric one. The values of place pression are referred to in absolute atmosphere (ATA). At sea level, there is a pression of $1 \mathrm{ATA}=760 \mathrm{mmHg}$. The environment air has $21 \%$ of oxygen in its composition, what means that place pression of oxygen $\left(\mathrm{pO}_{2}\right)$ is around $160 \mathrm{mmHg}$. In 2ATA, the pO2 will be about $320 \mathrm{mmHg}$. Nearly $97 \%$ of blood oxygen are transported by hemoglobin and only $3 \%$ is transported solved into plasma. When we breathe normobaric air, the oxygen arterial tension $\left(\mathrm{paO}_{2}\right)$ is about $100 \mathrm{mmHg}$ and the tension of oxygen in tissues is about $55 \mathrm{mmHg}$. However, with oxygen at $100 \%$ and pression of 3 ATA it is possible to increase the $\mathrm{paO} 2$ to $2000 \mathrm{mmHg}$ and the oxygen tension in tissues to nearly $500 \mathrm{mmHg}$, which allows supplying oxygen on about $60 \mathrm{ml}$ by blood liter (in comparing to $3 \mathrm{~mL}$ by liter at atmospheric pression) which is enough to provide oxygen consumption in resting tissues with no hemoglobin contribution ${ }^{30}$.

Hyper oxygenated plasma can transport oxygen to inaccessible areas to red blood cells, giving it to hypoxic and bad vascularized tissues. Besides, hyperbaric oxygen therapy can have action on the infections caused by many mechanisms ${ }^{31}$.

Although treatment by hyperbaric oxygen therapy may cause an effect on healing of normal wound with no complications, it can be more effective on ischemic wounds or those with infection ${ }^{32}$. Its effects in improving normal colonic anastomosis or with ischemia have been studied ${ }^{17}$, however its action in normal colonic anastomosis under the presence of peritonitis is still controverse $\mathrm{e}^{28}$.

This study aims at evaluating the effect of $\mathrm{HBO}$ on the mechanical resistance of anastomosis performed in rats' distal colon presenting peritonitis induced by ligature and cecal punction.

\section{Methods}

This research was approved by the Ethical Commission on Animal Experimentation of the Institute of Biology CEEAIB-UNICAMP, according to the ethical principles adopted by Brazilian Animal Experimentation College - COBEA (Protocol number 923-1).
Forty five male rats (Rattus norvegicus albinus, Rodentia mammalia) were used. They belonged to Wistar line with weight ranging from 350 to 400 grams and age around 100 to 110 days. The experiments were performed at the laboratory of surgical technique experimental medicine and surgery at the University of Campinas - UNICAMP. The dark/light cycle was characterized by the action of artificial light for a period of 12 hours a day, being temperature and humidity the same of general environment. Water and food were offered to the animals for free during all the experiment. There was no preview fasting to the surgical act.

The rats were randomly grouped in three groups of 15 animals in each one. Anesthesia was performed through the veins with caudal vein punction. It was used sodic pentobarbital at the dose of 30 milligrams by kilograms of weight.

In Control Group (CG), the animals underwent laparotomy, manipulation of bowels laps, ligature and resection of bigger omentum and spermatic funiculus fat and abdomen closure. After six hours, they were anesthetized again and underwent laparotomy followed by section and termini-terminal anastomosis in descending colon with apart seromuscular extramucous stitches with monofilament line of polypropylene 7.0. They were kept breathing in environment air.

In Peritonitis Group (PG), after manipulating the bowels laps, it was performed identification and mobilization of cecum and a maneuver of malaxing the intraluminal content of ascending colon into proximal direction in order to fill cecum with feces. Then, it was proceeded the partial ligature of cecum with monofilament line of polypropylene 4.0 , immediately below the ileocecal valve, not involving mesentery, in order to improve intraluminal pressure but not causing ischemia. Afterwards, with a needle 40 by 1,2 millimeters, it was performed 10 punctions on the anti-mesenteric cecum rim, 5 millimeters distant among them, on the total of five centimeters extension. There was a fecal content extravasation by the holes performed. Cecum was replaced into cavity and abdomen was closed. After six hours, the anastomosis was performed by a new operation. The rats were kept breathing in environment air as in the Control Group.

In the Hyperbaric Chamber Group (HCG), the surgical act was similar to Peritonitis Group; however, the rats were placed in an experimental hyperbaric chamber to inhale oxygen at $100 \%$, at 2 ATA, for 120 minutes, after recovering from anesthesia. Each session of hyperbaric oxygen therapy was daily repeated at the same time for four consecutive days. At session intervals, rats were kept breathing environment air.

No antibiotics or parenteral hydration was applied during experiment. Euthanasia was performed on the fourth post-surgical day with a letal dose of sodic tionembutal at 3\% in caudal vein. The abdominal cavity was open and the colon segment of four centimeters containing anastomosis was withdrawn and underwent intraluminar cleaning.

These specimens were submerged into a Becker cup containing physiologic solution at 37-centigrade degrees and papaverine chloridrate at 250 milligrams per liter concentration. This procedure was performed with the purpose of minimizing spasms caused by the manipulation of the colon segments. After 30 minutes, these segments were taken out of solution and were submitted to the Total Energy of Rupture biomechanical test (ETR). 

(Figure 1):

This test is composed by the following components

1. Proof body (descendent colon segment) (Figure 1a);

2. Precision balance Mettler-Toledo SB8000 (Figure 1b);

3. Strength cell from the precision balance Mettler-Toledo SB8000 (Figure 1c);

4. Serial port from the precision balance Mettler-Toledo SB8000 (Figure 1d);

5. Traction system B.Braun 871.012 (Figure 1e);

6. Serial communication cable (Figure 1f);

7. Personal Computer with serial interface RS232 and the Biomechanical Data Acquisition and Analysis System, version 2.0 (SABI 2.0) (Figure 1g);

8. Polygraph Siemens-Elema/Modelo 804 Mingograft (Figure 1h);

9. Catheter Cannon $n^{\circ} 18$ with the light closed (Figure 1i);

10. Catheter Cannon $n^{\circ} 18$ with the light open (Figure 1j);

11. Triple-via plug attached at the supporter (Figure 1k);

12. Plastic syringe $(10 \mathrm{ml})$, placed at the polygraph transducer (Figure 11).

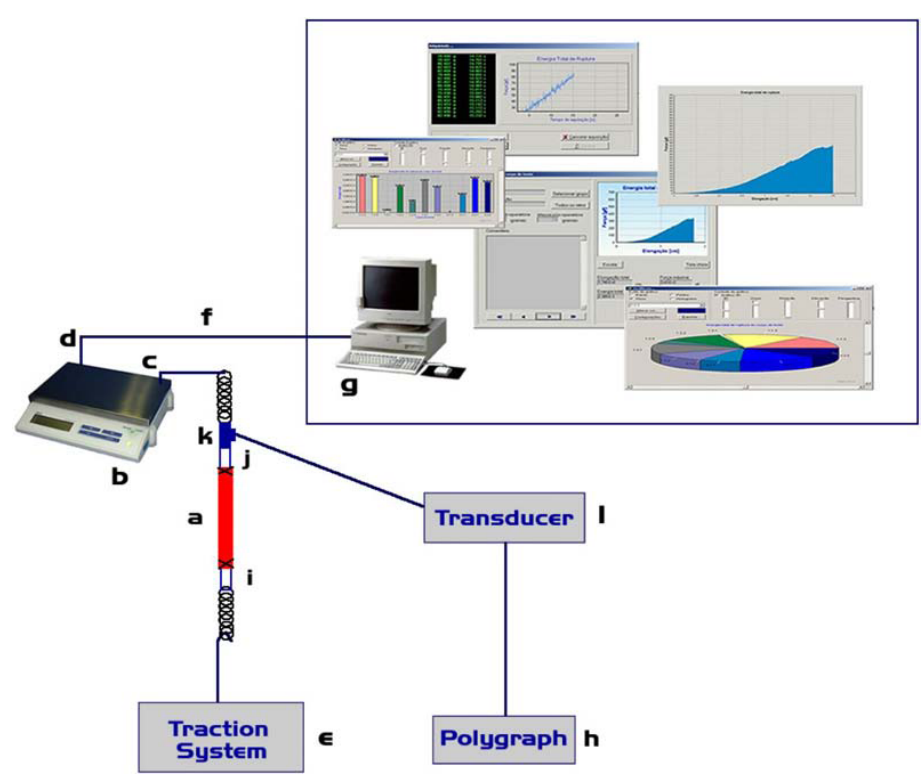

FIGURE 1 - Schematic representation of ETR. a) descendent colon segment, b) precision balance, c) strength cell, d) serial port, e) traction system, f) serial communication cable and SABI 2.0, g) computer with serial interface and SABI 2.0, h) polygraph, i) catheter cannon (closed light), j) catheter cannon (open light), k) triple-via plug attached to the supporter and l) polygraph transducer
ETR test was performed following the protocol described by WU et al. ${ }^{33}$. The force generated by the traction system was transferred to the specimen and detected by the precision balance strength cell. The computer containing SABI 2.0 received the force values, at a rate of three packages of data per second, sent by the balance. This system, in real time, draws the graph of the function Force x Elongation. SABI 2.0 automatically calculates the delimited area under this function through numerical integration using the Trapezoidal Rule method. This area corresponds to the Total Energy of Rupture (Figure 2). A constant velocity of one centimeter per minute was maintained during the essay ${ }^{34}$.

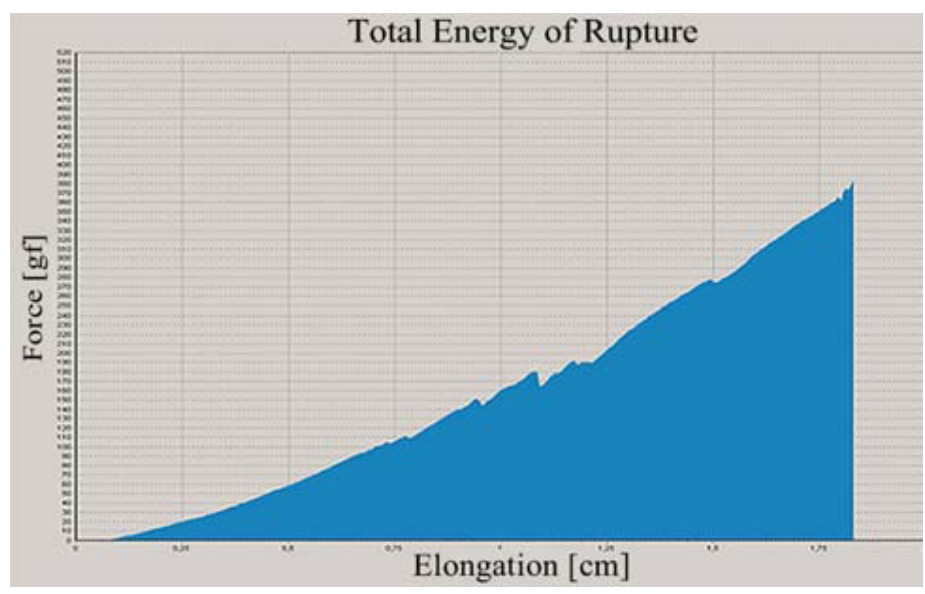

FIGURE 2 - Graph Force (gram force) x Elongation of rupture (cm). The area under this function represents the total energy of rupture

\section{Results}

There were no deaths and the animals had a good evolution in Control Group. There were six deaths at the first 24 hours in Peritonitis Group and in Hyperbaric Chamber Group there were five deaths at the first 24 hours and one death at 48 hours post-surgical. The animals in the last two groups had an evolution in first 48 hours although they had little movement in the cage. They stayed curved in abdomen flexion position, with fur erection and accented abdominal distension.

Euthanasia was performed at the fourth post-surgical day and the abdomen cavities were opened and described.

In the Control Group, the cavities were normal and the anastomosis were in full. The Peritonitis and Hyperbaric Chamber Groups presented themselves with macroscopic signs of diffuse peritonitis, as the presence of fetid smell, accented distension of bowels laps, great quantity of free liquid into cavity and presence of purulent points spread through the entire cavity or blocked by the bowels laps. The cecum was distend and showed signs extravasation of feces by the punction holes. There were adherences of cecum mainly with laps of tenuous bowels and, sometimes, with stomach or spleen. It was not observed dehiscence of the anastomosis in no animal, including the 12 ones that died (Figure 3). 


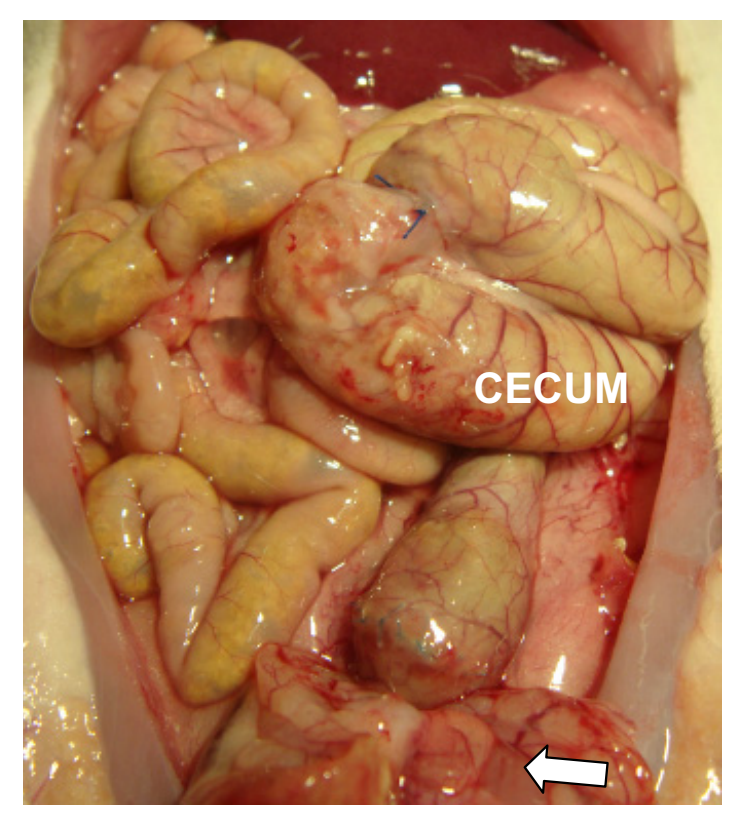

FIGURE 3 - Aspect of the abdominal cavity of animal in the HCG: presence of great quantity of free liquid in the cavity, distension of the tenuous bowels laps and cecum, purulent collections spread. Full anastomosis (sign)
The results of Total Energy Rupture, in gf.cm, reached by biomechanical test are represented at Table 1 and Figure 4.

TABLE 1 - Values of Total Energy Rupture, in gf.cm, in the animals of CG, PG and $\mathrm{HCG}$

\begin{tabular}{cccc}
\hline Rat 1 & CG Group & PG Group & HCG Group \\
Rat 2 & 238,40 & 149,90 & Death \\
Rat 3 & 215,60 & Death & Death \\
Rat 4 & 224,60 & 166,20 & Death \\
Rat 5 & 186,00 & 134,10 & Death \\
Rat 6 & 120,50 & 102,10 & 151,20 \\
Rat 7 & 233,30 & 160,10 & 132,80 \\
Rat 8 & 314,90 & 82,09 & 107,10 \\
Rat 9 & 109,30 & Death & 151,30 \\
Rat 10 & 221,00 & 224,60 & 56,80 \\
Rat 11 & 254,40 & 28,87 & 43,21 \\
Rat 12 & 144,20 & Death & Death \\
Rat 13 & 137,30 & Death & Death \\
Rat 14 & 152,80 & 102,20 & 260,90 \\
Rat 15 & 226,50 & Death & 151,10 \\
Average & 165,50 & Death & 144,60 \\
\hline
\end{tabular}

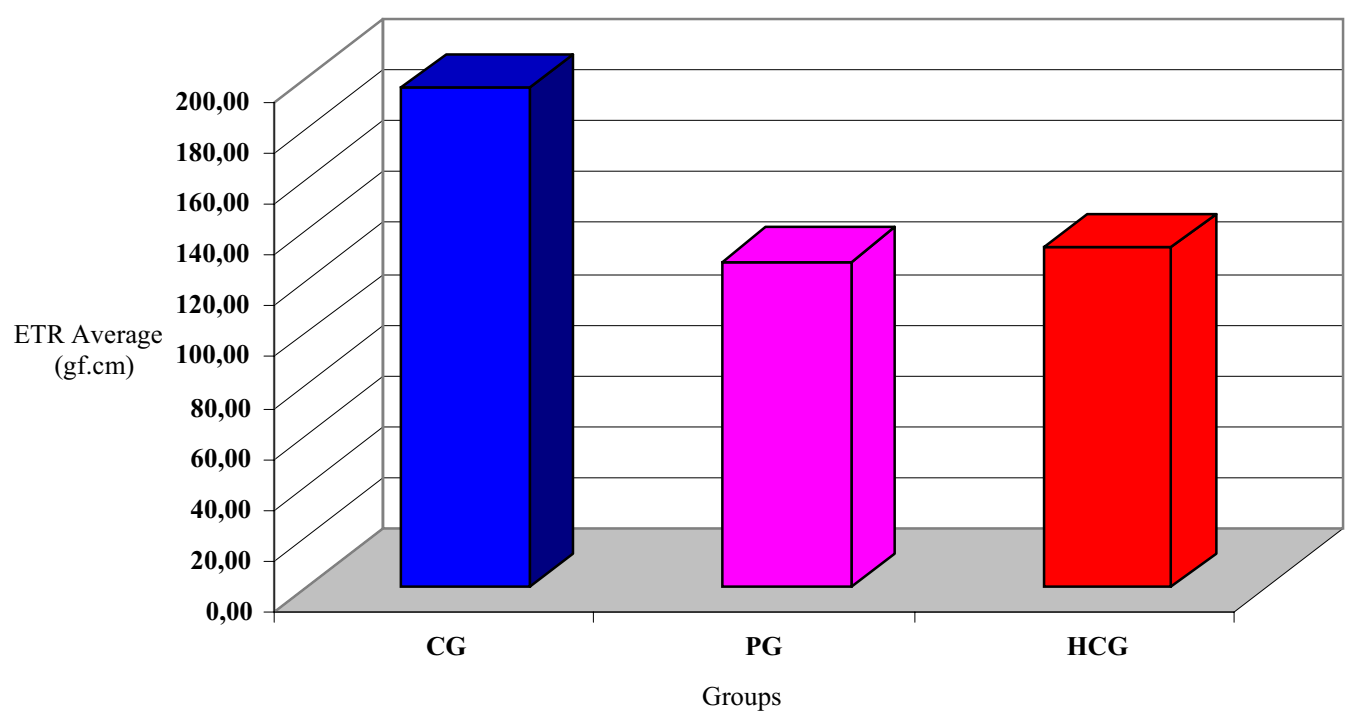

FIGURE 4 - Graphic distribution of total energy rupture values, in gf.cm, belonging to the CG, PG and HCG 
When comparing the variable of Total Energy Rupture regarding the groups (Control, Peritonitis and Hyperbaric Chamber) it was used the Variance Analysis (ANOVA) (Figure 5).

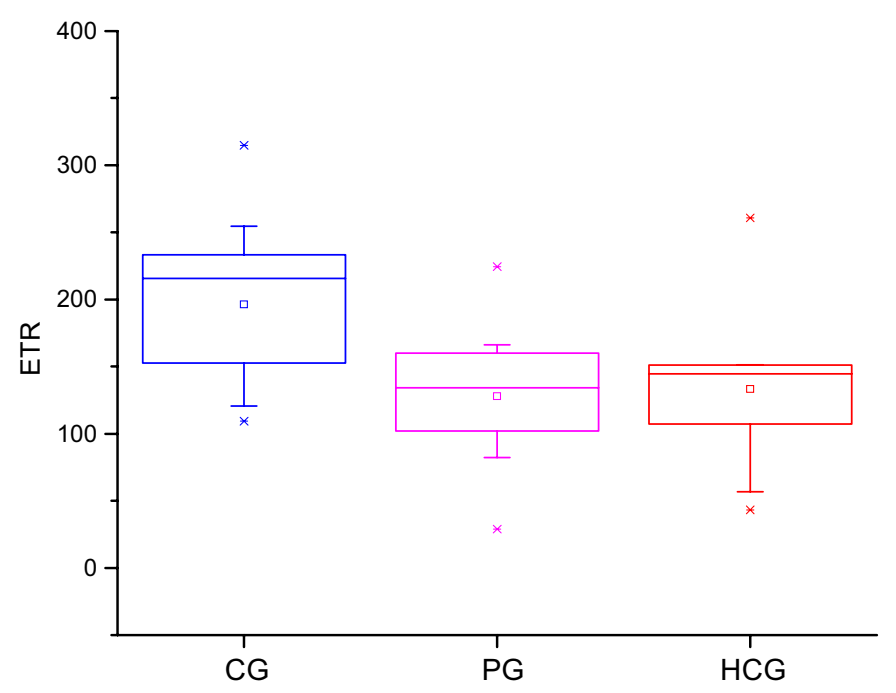

FIGURE 5 - "Box-plot" graphic of ranging total rupture energy by group

When the difference was significant, it was performed tests of multiple comparison (Tukey Test) to identify the differences (Table 2).

TABLE 2 - Comparison among groups by Tukey Test

\begin{tabular}{lc}
\hline Tukey Test & Alpha= $\mathbf{0 . 0 5}$ \\
Control Group x Peritonitis Group & Significant \\
Control Group x Hyperbaric Chamber Group & Significant \\
Peritonitis Group x Hyperbaric Chamber Group & No Significant \\
\hline
\end{tabular}

Control Group is statistically significant from Peritonitis and Hyperbaric Chamber Groups. However, Peritonitis Group does not present statistical difference regarding Hyperbaric Chamber Group.

\section{Discussion}

Cicatrization is the matching point of all surgical areas. It is known that, under certain adversity conditions it does not take place satisfactorily. Particularly, the presence of intraperitoneal sepsis is a reason of fear by he surgeons and, as a rule, their anastomosis are protected by stomas in this situation. This research aimed at analyzing the effect of hyperbaric hyper oxygenation on the mechanical resistance of anastomosis performed on rats' distal colon on the presence of diffuse peritonitis induced by ligature and cecal punction.
The peritoneum infection is one of the main factors that interfere in the cicatrization of anastomosis performed in colon $^{28,29,31,35,36}$.

Naresse et al. ${ }^{20}$ and Ahrendt et al. ${ }^{36}$, showed that fecal peritonitis was harmful to bowels cicatrization, what could favor anastomotic dehiscence.

Gutman et. $a l .{ }^{19}$ and Biondo-Simões et al. ${ }^{24}$, stated that peritonitis had no effect on the pressure anastomosis explosion.

de Hingh et al..$^{25}$, observed that peritonitis reduce mechanical resistance of colic anastomosis in the third postsurgical day, getting back to normal stage on the fifth day.

In this research, peritonitis was induced with a model of ligature and cecal punction, described previously by Wichterman et $a l .{ }^{37}$, performing 10 punctions in the antimesenteric rim of cecum. There was a significant reduction of mechanical resistance of anastomosis on the fourth post-surgical day. Similarly, the model caused high mortality, being useful for this kind of study. After peritonitis induction, the animals underwent surgery six hours after for the performance of anastomosis. It was tried to simulate what normally happens in everyday practical life.

HBO has been studied in experimental peritonitis. So, Mantovani et al. ${ }^{38}$, reported that it reduced the mortality rate in fecal peritonitis model. In this research, mortality was he same, $40 \%$, in the group presenting diffuse fecal peritonitis with and without using $\mathrm{HBO}$.

$\mathrm{HBO}$ also had its effects evaluated in the cicatrization of colic anastomosis. It was able of improving mechanical resistance of anastomosis with or without presence of induced ischemia ${ }^{17,39}$.

Yagci et al. ${ }^{18}$, used hyperbaric oxygen pre and postsurgically in normal and ischemic colic anastomoses in rats and the concluded that HBO increased the mechanical parameters in ischemic anastomosis, but the increasing in the values of pression of explosion in normal anastomosis was not statistically significant.

Rocha et l. $^{40}$, showed that HBO does not improve the pression of explosion in rats colic laps with progressive levels of ischemia.

Although HBO seems to be efficient in colic anastomosis in the presence of ischemia, its use in the presence of diffuse peritonitis stills seems to be controversial.

Sucullu et al. ${ }^{28}$, studied the effect of HBO, at 2,5 ATA, in colonic anastomosis under the presence of experimentally induced peritonitis by ligature and cecal punction. The animals got antibiotics and resuscitation liquids. The authors concluded that HBO improved the explosion pressure, but it did not alter histological evaluation and the levels of hydroxyproline in the anastomosis.

In this research, Total Energy Rupture (ETR) biomechanical test was elected in order to check anastomoses quality, as described by Wu et al. ${ }^{33}$. Control Group presented an average ETR of 196,26 gf.cm, statistically different from Peritonitis Group, showing that the peritonitis model acted deleteriously in anastomosis cicatrization weakening their mechanical resistance. ETR average was 127,8 gf.cm in Peritonitis Group and 133,22 gf.cm in Hyperbaric Chamber Group. There was no statistically difference between both groups. So, HBO did not revert the peritonitis damages on the mechanical resistance of anastomosis on the fourth post-surgical day. 


\section{Conclusion}

Hyperbaric oxygen therapy did not alter the mechanical resistance of anastomosis performed in distal colon of rats under the presence of peritonitis induced by ligature and cecal puncture.

\section{References}

1. Choi HK, Law WL, Ho JW. Leakage after resection and intraperitoneal anastomosis for colorectal malignancy: analysis of risk factors. Dis Colon Rectum. 2006;49(11):1719-25.

2. Kingham TP, Pachter HL. Colonic anastomotic leak: risk factors, diagnosis and treatment. J Am Coll Surg. 2009;208(2):269-78.

3. Konishi T, Watanabe T, Kishimoto J, Nagawa H. Risk factors for anastomotic leakage after surgery for colorectal cancer: results of prospective surveillance. J Am Coll Surg. 2006;202(3):439-44.

4. Cohen SR, Cornell CN, Collins MH, Sell JE, Blanc WA, Altman RP. Healing of ischemic colonic anastomoses in the rat: Role of antibiotic preparation. Surgery. 1985;97(4):443-6.

5. Hershey SD, Lucas CE, Ledgerwood AM, Cushing R. Effects of antimicrobials on wound healing. Surg Forum. 1987;33:30-1.

6. Shandall AA, Willians GT, Hallett MB, Young HL. Colonic healing: a role for polymorphonuclear leucocytes and oxygen radical production. Br J Surg. 1986;73(3):225-8.

7. Garcia JG, Criado FJ, Persona MA, Alonso AG. Healing of colonic ischemic anastomoses in the rat: role of superoxide radicals. Dis Colon Rectum. 1998;41(7):892-5.

8. Yazdi PG, Miedema BW, Humphrey L. Immediate postoperative 5-FU does not decrease colonic anastomotic strength. J Surg Oncol. 1998;69(3):125-7.

9. Mantovani M, Leonardi LS, Alcântara FG, Hadler WA. Estudo comparativo entre suturas em um e dois planos no intestino delgado na vigência de drogas imunossupressoras: trabalho experimental no cão. Rev Paul Med. 1977;89:35-41.

10. Yarimkaya A, Apaydin B, Unal E, Karabicak I, Aydogan F, Uslu E, Erginoz E, Artis T, Eyuboglu E. Effects of recombinant human growth hormone and nandrolone phenylpropionate on the healing of ischemic colon anastomosis in rats. Dis Colon Rectum. 2003;46(12):1690-7.

11. Irvin TT, Hunt TK. The effect of trauma on colonic healing. Br J Surg. 1974;61(6):430-6.

12. Brito MV, Koh IH, Lamarão LG, Damous SH. Effect of hypovolemic shock in anastomose of small intestine of rats. Arq Gastroenterol. 2001;38(2):116-24.

13. Pereira YE, Fagundes JJ, Morandini RC, Ayrizono Mde L, Nascimento RB, Leal RF, Góes JR, Mantovani M, Coy CS. Hemorrhagic shock influence on colonic anastomoses in rats. Evaluation of rupture by liquid distension resistance test. Acta Cir Bras. 2008;23(3):237-42.

14. Bolzam-Nascimento R, Coy CS, Pereira YE, Leal RF, Reis RC, Mantovani M, Ayrizono Mde L, Chung WF, Fagundes JJ. Influence of omentoplasty on colonic anastomosis in animals submitted to hemorrhagic shock in rats. Acta Cir Bras. 2009;24(3):233-8.

15. Wu FC, Ayrizono Mde L, Fagundes JJ, Coy CS, Góes JR, Leonardi LS. Estudos biomecânicos da ação de aderências sobre anastomose cólica: trabalho experimental em ratos. Acta Cir Bras. 2003;18(3):216-23.

16. Mochizuki M, Wu FC, Coy CS, Ayrizono Mde L, Góes JR, Fagundes JJ. Effect of guided adhesions on ischemic colic anastomoses in rats. Acta Cir Bras. 2005;20(3):247-52.

17. Hamzaoglu I, Karahasanoglu T, Aydin S, Sahin DA, Carkman S, Sariyar M, Alemdaroglu K. The effects of hyperbaric oxygen on normal and ischemic colon anastomoses. Am J Surg. 1998;176(5):458-61.
18. Yagci G, Ozturk E, Ozgurtas T, Gorgulu S, Kutlu OC, Topal T, Cetiner $\mathrm{S}$, Tufan T. Preoperative and postoperative administration of hyperbaric oxygen improves biochemical and mechanical parameters on ischemic and normal colonic anastomoses. J Invest Surg. 2006;19(4):237-44.

19. Gutman M, Klausner JM, Lelcuk S. Fecal peritonitis - the effect on anastomotic healing. Eur Surg Res. 1993;25(6):366-9.

20. Naresse LE, Souza CV. Efeito da peritonite fecal na cicatrização do cólon distal no rato: avaliação anatomopatológica, estudo da força de ruptura e da hidroxiprolina tecidual. Acta Cir Bras. 1993;8(2):48-53.

21. Minossi JG, Naresse LE, Leite CVS, Rodrigues MAM, Angeleli MAY, Curi PR, Kobayasi S. Fecal peritonitis in the rat. Alterations of the distal colon wall. A biomechanical and anatomopathologic study. Acta Cir Bras. 1994;9(1):12-8.

22. Ahrendt GM, Gardner K, Barbul A. Loss of colonic structural collagen impairs healing during intra-abdominal sepsis. Arch Surg. 1994;129(11):1179-83.

23. Orlando MD, Chendrasekhar A, Bundz S, Burt ET, Moorman DW, Timberlake GA. The effect of peritoneal contamination on wound strength of small bowel and colonic anastomoses. Am Surg. 1999;65(7):673-5.

24. Biondo-Simões MLP, Greca FH, Bryk Junior A, Komatsu MCG, Bittencourt FO, Greca LM. Influência da peritonite sobre a síntese de colágeno em anastomoses do cólon distal: estudo experimental em ratos. Acta Cir Bras. 2000;15 Suppl 3:69-73.

25. de Hingh IH, de Man BM, Lomme RM, van Goor H, Hendriks T. Colonic anastomotic strength and matrix metalloproteinase activity in an experimental model of bacterial peritonitis. Br J Surg. 2003;90(8):981-8. 26. Aytekin FO, Teke Z, Aydin C, Kabay B, Yenisey C, Sacar S, Demir EM, Tekin K. Effects of a membrane-permeable radical scavenger, Tempol, on healing of colonic anastomoses in the cecal ligation and puncture model of polymicrobial sepsis in rats. Am J Surg. 2007;193(6):723-9.

27. Teke Z, Sacar S, Yenisey C, Atalay AO, Kavak T, Erdem E. Role of activated protein $\mathrm{C}$ on wound healing process in left colonic anastomoses in the presence of intra-abdominal sepsis induced by cecal ligation and puncture: an experimental study in the rat. World J Surg. 2008;32(11):2434-43. 28. Sucullu I, Sinan H, Filiz AI, Yildiz S, Yucel E, Kurt Y, Akin ML. The effects of hyperbaric oxygen therapy on colonic anastomosis in rats with peritonitis. J Invest Surg. 2008;21(4):195-200.

29. Uludag M, Citgez B, Ozkaya O, Yetkin G, Ozcan O, Polat N, Isgor A. Effects of amniotic membrane on the healing of primary colonic anastomoses in the cecal ligation and puncture model of secondary peritonitis in rats. Int J Colorectal Dis. 2009;24(5):559-67.

30. Tibbles PM, Edelsberg JS. Hyperbaric-oxygen therapy. N Engl J Med. 1996;334(25):1642-8.

31. Kaide CG, Khandelwal S. Hyperbaric oxygen: applications in infectious disease. Emerg Med Clin North Am. 2008;26(2):571-95.

32. Gottrup F. Oxygen in wound healing and infection. World J Surg. 2004;28(3):312-5.

33. Wu FC, Lee HD, Machado RB, Dalmás S, Coy CS, Góes JR, Fagundes JJ. Energia total de ruptura: um teste biomecânico para avaliação de material biológico com propriedade viscoelástica não linear. Acta Cir Bras. 2004;19(6):609-16.

34. Wu FC, Lee HD, Niz MA, Ayrizono Mde L, Coy CS, Góes JR, Fagundes JJ. Comparative study of descendent colon rupture resistance considering traction force of rupture and total energy of rupture in rats. Acta Cir Bras. 2006;21(2):97-100.

35. Irvin TT. Collagen metabolism in infected colonic anastomoses. Surg Gynecol Obstet. 1976;143(2):220-4.

36. Ahrendt GM, Tantry US, Barbul A. Intra-abdominal sepsis impairs colonic reparative collagen synthesis. Am J Surg. 1996;171(1):102-7.

37. Wichterman KA, Baue AE, Chaudry IH. Sepsis and septic shock - a review of laboratory models and a proposal. J Surg Res. 1980;29(2):189-201. 
38. Mantovani M, Iazzetti PE, Rizoli SB, Neto AC, Filho AB, Leonardi LS. Efeitos da oxigenoterapia hiperbárica na peritonite fecal experimental. Rev Col Bras Cir. 1989;16(2):84-6.

39. Guzel S, Sunamak O, AS A, Celik V, Ferahman M, Nuri MM, Gazioglu E, Atukeren P, Mutlu O. Effects of hyperbaric oxygen and Pgg-glucan on ischemic colon anastomosis. World J Gastroenterol. 2006;12(9):1421-5. 40. Rocha AA, Coy CS, Góes JR, Ayrizono Mde L, Wu FC, Fagundes JJ. Comparative study of the hyperbaric hyperoxygenation in ischemic colonic loops in rats. Acta Cir Bras. 2007;22(2):85-91.

\section{Acknowledgments}

To Ana Cristina de Moraes and William Adalberto Silva from the Medicine and Experimental Surgery Center (NMCE), University of Campinas (UNICAMP) for technical support.

Conflict of interest: none

Financial source: none

\section{Correspondence:}

Antonio Angelo Rocha

Praça Francisco Escobar, 201/36

37701-027 Poços de Caldas - MG Brazil

Phone/Fax: (55 35)3721-1831

angelorocha@terra.com.br

Received: January 20, 2010

Review: March 18, 2010

Accepted: April 14, 2010

\section{How to cite this article}

Rocha AA, Leal RF, Ayrizono MLS, Chung WF, Coy CSR, Lee HD, Fagundes JJ. Hyperbaric oxygen therapy and mechanical resistence of the colonics anastomosis in rats with peritonitis. Acta Cir Bras. [serial on the Internet] 2010 July-Aug;25(4). Available from URL: $\underline{\text { http://www.scielo.br/acb }}$ 